\title{
Population dynamics and conservation management of Himalayan mahseer (Tor species) in riverine aquatic ecosystem in Garhwal region of Uttarakhand (India)
}

\section{Davendra Singh Malik}

Department of Zoology and Environmental Science, Gurukula Kangri University, Haridwar-249404 (Uttarakhand), INDIA E-mail: malikdsgkv@gmail.com

\begin{abstract}
The mahseer, an Indian carp (Tor species) known as 'Sport fish' continues to be decimated by the large scale natural and anthropogenic factors and categorized as threatened fishes in India. The present research data revealed that total species richness of 33 and 24 number of fish species were identified in river Ganga and Yamuna respectively. The size group of mahseer $(400-460 \mathrm{~mm})$ recorded as a dominant size of catch composition and contributed about $36.8 \%$ and $42.6 \%$ based on different sampling sites in river Yamuna and Ganga respectively. The populations of Tor tor, T. putitora have shown a decreasing trend at very alarming rate and influenced the sex ratio, maturity size and natural breeding condition. Only 12.5 to $14.8 \%$ mahseer female brooders have shown maturity phase or emenable to release ova during particular breeding seasons. The fecundity of mature female fish brooders ranged from 2500-4500 no. of eggs during July-August. The current status of mahseer fishery may be attributed to the over exploitative nature in riverine system. "In situ and Ex-situ" breeding techniques should be practiced for enhancement of viable population size of mahseer species to restore the genetic loss under mahseer conservation programme in aquatic ecosystem of Himalayan region.
\end{abstract}

Keywords: Mahseer fish, Tor species, Population dynamics, Fish conservation, Riverine ecosystem

\section{INTRODUCTION}

India is one of the Megabiodiversity countries in the world and occupies ninth position in terms of fresh water mega biodiversity (Mittermeier and Mittemeier, 1997). In India, there are 2500 species of fishes, of which 930 inhabited in fresh water (Kar, 2003 and Jayaram, 1999). The principal endemic and exotic fishes occurring in the natural upland waters of the Himalaya are about 225 species and contributed approximately $9.32 \%$ of the fish germplasm resources of India (Das, 1994). In Uttarakhand, the Himalayan mahseer (Tor species) is largely confined to the lotic and lentic habitats e.g. streams, rivers and lakes. It is a fresh water largest scale carp belonging to the family cyprinidae having a wide distribution occurring all along the foot hills of Himalaya (Day, 1878, and Singh et al., 1987). Fishery resource of the Yamuna river in Garhwal Himalaya is not well known except some contributions (Nath et al., 1994, Soni 1998 and Moza et al., 2005), but the report on the status of fish diversity and biomass in Yamuna river at the foot hills of Garhwal Himalaya is scanty, as while, the foot hill region of lesser Himalayan zone at Doon velley formed a unique transition zone and reflected the rich fish diversity in the Yamuna river and its tributaries. The mahseer has been categorized as one of the threatened fish species of the
Himalayan region (NCA, 1976) and has necessity for conservation of mahseer resources in riverine system of Garhwal Himalaya. The ecological stress on the mahseer population occurred due to many natural and anthropogenic activities specially developing hydroelectrical projects. The artificial propagation or induced breeding programme has played a major role to maintaining endemic fish species diversity in aquatic system of Himalayan region. 'In situ' conservation programme would be more dynamic steps for enhancing the natural stocks of mahseer species in riverine system of Garhwal region at Uttarakhand.The present study provided an existed fish diversity, population status of mahseer and an induced breeding practice was tried to enhance the mahseer fish seeds for stocking in Ganga and Yamuna rivers.

\section{MATERIALS AND METHODS}

Study sites: Garhwal Himalaya lies in between the latitudes $29^{\circ} 26^{\prime}$ to $31^{\circ} 28^{\prime} \mathrm{N}$ and longitude $77^{\circ} 49^{\prime}$ to $80^{\circ} 06^{\prime} \mathrm{E}$, as almost central position in the long Himalayan sweep. The main stream of river Ganga originates from the confluence point of river Bhagirathi and river Alaknanda at Devprayag. The combined river flow down through Byasghat, Byasi, Gular, Laxmanjhula and Rishikesh to Hardwar and Yamuna river system extends from Yamunotri 
Table 1. Status of fish fauna in Ganga and Yamuna river at the foothills of Garhwal Himalaya.

\begin{tabular}{|c|c|c|}
\hline S. No. & Fish species & Ecological status \\
\hline 1 & Labeo boga (Hamilton-Buchanan) & Intermediate \\
\hline 2 & *Labeo dero (Hamilton-Buchanan) & Vulnerable \\
\hline 3 & Labeo gonius(Hamilton-Buchanan) & Intermediate \\
\hline 4 & Puntius sarana sarana (Hamilton-Buchanan) & Vulnerable \\
\hline 5 & *Puntius sophore (Hamilton-Buchanan) & Rare \\
\hline 6 & Puntius ticto (Hamilton-Buchanan) & Rare \\
\hline 7 & Tor tor (Hamilton-Buchanan) & Vulnerable \\
\hline 8 & Tor putitora (Hamilton-Buchanan) & Vulnerable \\
\hline 9 & Barilius bendelisis (Hamilton-Buchanan) & Intermediate \\
\hline 10 & Barilius vagra (Hamilton-Buchanan) & Rare \\
\hline 11 & Raimas bola (Hamilton-Buchanan) & Endangered \\
\hline 12 & Danio (Brachydanio) rerio (Hamilton-Buchanan) & Rare \\
\hline 13 & Danio devario (Hamilton-Buchanan) & Rare \\
\hline 14 & *Esomus danricus (Hamilton-Buchanan) & Rare \\
\hline 15 & Rasbora daniconius (Hamilton-Buchanan) & Vulnerable \\
\hline 16 & Schizothoraichthys progastus (McClelland) & Intermediate \\
\hline 17 & Schizothorax plagiostomus (Heckel) & Intermediate \\
\hline 18 & $*$ Schizothorax sinuatus (Heckel) & Rare \\
\hline 19 & Crossocheilus latius latius (Hamilton-Buchanan) & Rare \\
\hline 20 & Garra gotyla gotyla (Gray) & Vulnerable \\
\hline 21 & *Nemacheilus beavani (Gunther) & Intermediate \\
\hline 22 & Nemacheilus botia (Hamilton-Buchanan) & Intermediate \\
\hline 23 & *Nemacheilus montanus (McClelland) & Endangered \\
\hline 24 & Nemacheilus savona (Hamilton-Buchanan) & Vulnerable \\
\hline 25 & Botia dario (Hamilton-Buchanan) & Rare \\
\hline 26 & *Mystus tengara (Bloch) & Rare \\
\hline 27 & *Clupisoma garua (Hamilton-Buchanan) & Vulnerable \\
\hline 28 & Bagarius bagarius (Hamilton-Buchanan) & Vulnerable \\
\hline 29 & Glyptothorax pectinopterus (McClelland) & Rare \\
\hline 30 & *Colisa fasciatus (Bloch and Schneider) & Vulnerable \\
\hline 31 & Xenentodon cancila (Hamilton-Buchanan) & Rare \\
\hline 32 & Channa gauchua (Bloch and Schneider) & Vulnerable \\
\hline 33 & Mastacembelus armatus (Lacepede) & Rare \\
\hline
\end{tabular}

* Above fish species not found in Yamuna river.

to Hathnikund barrage at Tajewallah in Garhwal region.

Collection of samples: The fish samples were obtained from upstream sites as in-between from Devprayag to Byasi Ghat and downstream sites of Veerbhadra barrage and Bhimgoda barrage located at Ganga river. In Yamuna river, the fish samples were collected from upstream sites in-between Kalsi and Dakpathar barrage and downstream sites in-between Dakpathar barrage to Asan barrage. Most of the fish samples were collected from the local fishermen, anglers from the river sites or fish landing sites. The fishermen were landed using gill nets and cast nets, the size of gill nets varied from $10 \times 5$ and $5 \times 2.5$ meters with mesh size of $8-10 \mathrm{~cm}$ respectively. The fishes were identified according to Talwar and Jhingran (1991) and Day (2007). The status of fish species in both rivers were categorized according to CAMP report (1998). The experimental fishing was done during April - May and July -September during 2007-08 with collaboration of Uttarakhand state fisheries to analyze the maturity stages of mahseer species and semi-intensive induced breeding programme. The hatching processes were done in regulated flow water hatchery of state fish farm situated at Dhakrani near the Yamuna river. Several breeding measures for experimental seed production and stock enhancement methods have been adopted by Sehgal and Malik (1991) and Ogale (2000).

\section{RESULTS AND DISCUSSION}

The fast changing ecology of upland waters seems to have primarily affected the well being of the fish species inhabiting in cold water aquatic bodies. The principal endemic and exotic fish species occurring in natural waters of Garhwal and Kumaon region are about 225 species (Sehgal, 1991). Among these, more than 100 endemic fish species occurred in aquatic system of Garhwal region. Fish fauna occurring in the Ganga river in the foothills of Garhwal Himalaya is quite rich and diversified. The fish species richness as 33 species belonging to 9 families, 7 sub families and 21 genera were observed in Ganga river. The fresh water fish diversity as 24 fish species belonging to 18 genera, 7 sub families and 8 families occurred in Yamuna river. The Cyprinids fishes exist in highest endemic fish species in both the rivers. The distribution pattern of fish species revealed 
Table 2. Experimental induced breeding (In Situ) of mahseer during, 2007 - 08.

\begin{tabular}{|c|c|c|c|c|c|c|}
\hline \multirow{2}{*}{$\begin{array}{l}\text { Breeding } \\
\text { months }\end{array}$} & \multirow{2}{*}{$\begin{array}{c}\text { No. of female } \\
\text { brooder }\end{array}$} & \multicolumn{2}{|c|}{ Size range of female brooders } & \multirow[t]{2}{*}{ Fecundity } & \multirow{2}{*}{$\begin{array}{c}\text { Hatching rate } \\
(\%)\end{array}$} & \multirow{2}{*}{$\begin{array}{c}\text { Fry survival } \\
\text { rate ( } \%)\end{array}$} \\
\hline & & Length(mm) & Weight( gm) & & & \\
\hline April & $3+4$ & $425-500$ & $650-1250$ & $2400-3000$ & $85.0-87.5$ & $75.0-78.5$ \\
\hline May & $4+6$ & $420-550$ & $650-1400$ & $2000-2750$ & $82.0-85.4$ & $77.0-80.0$ \\
\hline July & $3+2$ & $400-600$ & $600-1550$ & $2000-3000$ & $90.0-92.4$ & $78.0-82.4$ \\
\hline August & $8+8$ & $410-620$ & $600-1600$ & $3250-4500$ & $90.0-94.0$ & $80.0-90.0$ \\
\hline September & $6+4$ & $400-650$ & $600-1600$ & $2500-3500$ & $92.0-95.5$ & $80.0-90.0$ \\
\hline
\end{tabular}

that two species are endangered, 11 species are vulnerable and one species endangered, 9 fish species vulnerable in Ganga and Yamuna river respectively (Table 1). Jhingran (1990) also reported the population status of fresh water fishes in river of Himalayan region and mentioned one species was extinct, five were endangered and 22 fish species were rare in Ganga river. Khanna et al. (1998) mentioned about 35 fish species inhabited in Ganga river. Malik et al. (1998) recorded the fish diversity in relation to their ecological status in upland water of Himalayan regions. The present distributional pattern of fishes in downstream of both the rivers have shown drastic ecological changes and ultimately affected the fish species richness due to non-maintenance of the minimum water requirements and alteration of ecological characteristics for the maintaining endemic fish diversity. The fish catch composition studies revealed that the mahseer were contributed about $32.5 \%$ in upstream and $25.6 \%$ in downstream stretches of Yamuna river as while, $38.6 \%$ in upstream and $28.2 \%$ in downstream in Ganga river. The size of the fish as $350-450 \mathrm{~mm}$ was recorded as a dominant and maximum density of mahseer was recorded in the size ranging from $400-450 \mathrm{~mm}$ in length. The maximum size $(600 \mathrm{~mm}-700 \mathrm{~mm})$ fishes showed their minimum percentage (Fig.1). The present data indicated a sharp decline in size range as well as abundance of mahseer. Thus the mahseer fish species could be categorized as vulnerable or threatened fish species in Garhwal region at Uttarakhand. The decline trend of mahseer population in riverine system of Garhwal region

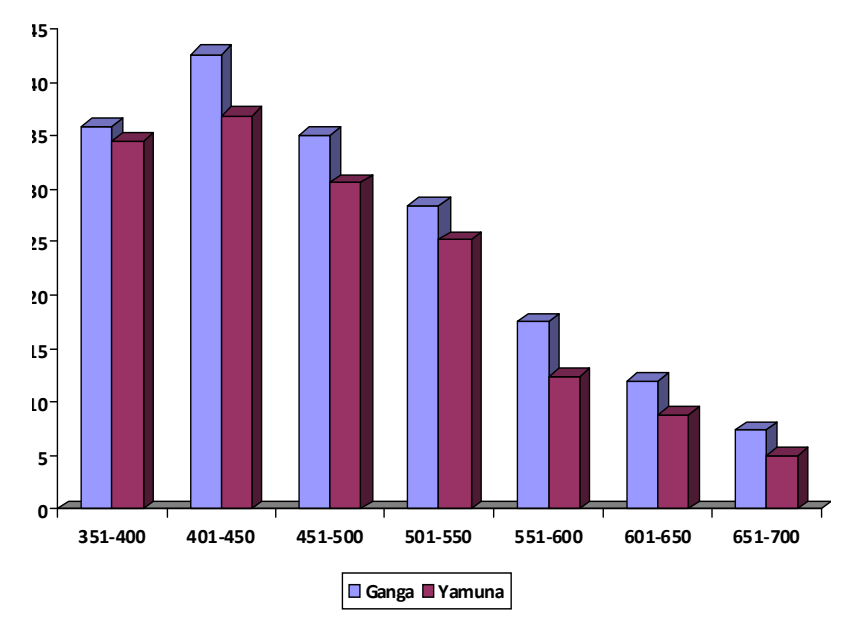

Fig.1. Average percentage of different size group of mahseer species in rivers. may be due to altering ecological characteristics by many anthropogenic factors as also described by Bhatt $e t a l$. (2000).

The male species of mahseer had maximum density in size range from $300-550 \mathrm{~mm}$ in both the rivers. The maximum percentages of female species of mahseer were recorded in the size ranging from $400 \mathrm{~mm}-450 \mathrm{~mm}$ as $15.8 \%$ and $11.2 \%$ in Ganga and Yamuna river respectively (Fig. 2 and 3 ). The sex ratios of male and female species of the fish were recorded about 6:1 and 4:1 in size range (300$350 \mathrm{~mm}$ ) were recorded but in the higher size range, the sex ratio about 3:1 was recorded in both the rivers. The seasonal sex ratio of mahseer showed that more males were present in upstream sites of river than females. Chaturvedi (1976) recorded the sex ratio of male and female to be 1:2 in T. tor while, Pathani (1978) observed sex ratio 1:1.33 for T. tor and 1: 1.56 for T. putitora in Bhimtal lake. The different sex ratios of female and male mahseer in the upstream and downstream of Ganga and Yamuna river may be due to population drift by the existing barrages on both rivers.

A trend of multiple spawning was observed in mahseer (T. tor and T. putitora) in Ganga and Yamuna rivers. The present observations revealed that matured mahseer fishes spawned in two seasons dominantly during April - May as the first set, while the second set being in JulySeptember. The similar seasonal breeding spawning periodicity pattern have also been described by Khan (1939) and Sehgal (1974 and 1992) in mahseer. In the present study, the regular field observations were showed

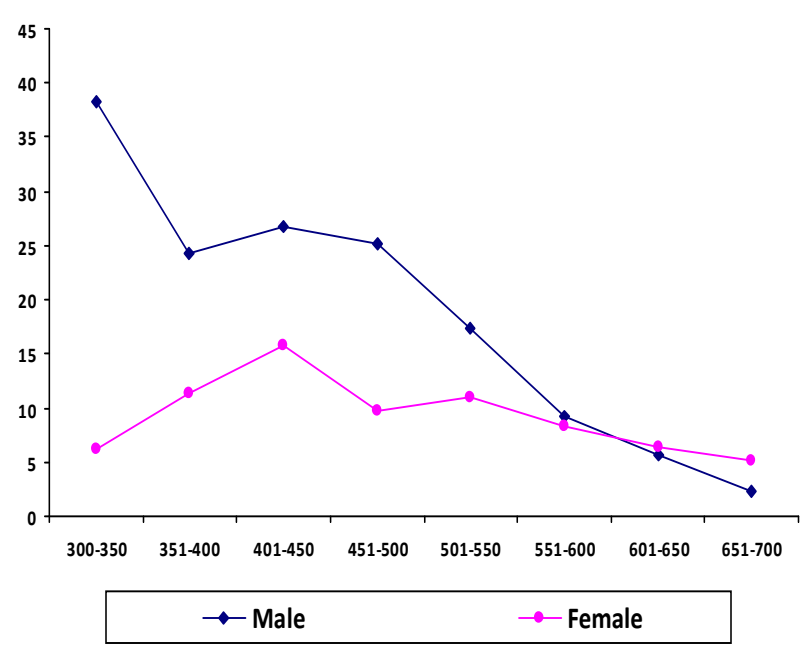

Fig. 2. Percentage of male and female mahseer in Ganga river. 


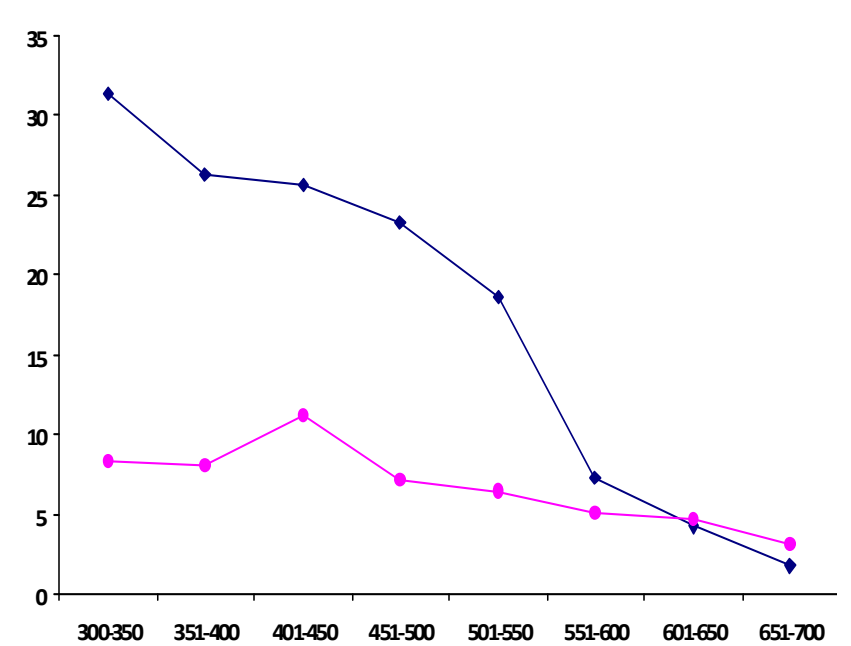

Fig. 3. Percentage of male and female mahseer in Yamuna river.

that mahseer fishes laid their eggs in two phases as in April-May and secondly in July-September, indicated two main natural breeding seasons i.e. pre-summer and rainy season in the riverine system of Garhwal region. Welcomme (1985) reported different ways of habitat restoration and fish conservation for endemic fishes and emphasized to declare fish sanctuaries in the selected upland water bodies as protected areas for preservation of endemic fishery resources, especially those endemic fishes, which are categorized as endangered, vulnerable, rare and intermediate. These natural protected riverine habitats would be contributing for development of brood fishes and growth of juveniles of endemic fishes. Artificial propagation or induced breeding project for intensive production of stocking of fish seed of mahseer fish species in the upland water bodies are the only solution to save the threatened fish species of mahseer. Induced breeding is an important method of mahseer aquaculture including hatchery practice and nursery management effort made by Sehgal and Kumar (1977). Sehgal and Malik (1996) have tremendously introduced dry stripping method for induced breeding practices of mahseer in aquatic ecosystem at Uttarakhand. A flow model diagram has shown the complete process of induced breeding as 'In situ' conservation steps to replenish the fingerlings of the mahseer in the natural water bodies of Garhwal Himalaya (Fig.4). The present study of matured female brooders of mahseer indicated that only 12.5 to $14.8 \%$ mahseer female brooders showed the maturity phase or emenable to release ova during particular breeding seasons in river Ganga and Yamuna. The fecundity of mature female fish brooder ranged 2500-4500 no. of eggs during breeding seasons i.e. April-May and July to September. The percentage of hatching and rate of cumulative survival of fry ranged as 82.0-95.5 and 75.0 -

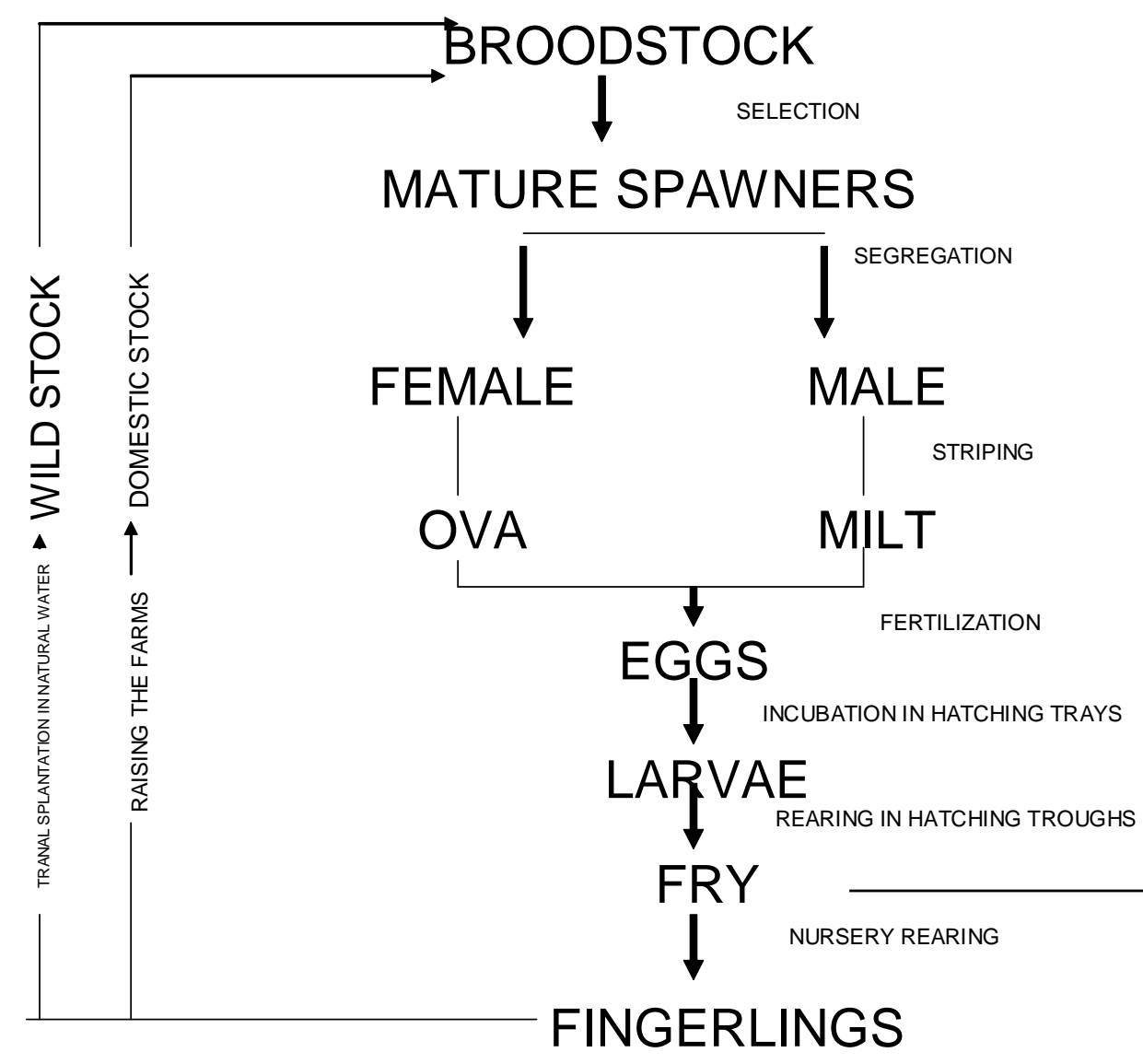

Fig. 4. Induced breeding operation ('In situ' conservation) of Mahseer. 
90.0 respectively depending upon the physico-chemical characteristics of water in hatching troughs and produced maximum fish seed quantity in relation to used number of female brooders in comparison to natural breeding of mahseer species that occurred in Ganga and Yamuna river (Table 2). By using breeding techniques such as induced or striping method, the intensive mahseer seed production could be maximum for the subsequent transplantation in the Ganga and Yamuna rivers. About one lakh mahseer fingerlings sizes $25-35 \mathrm{~mm}$ were stocked to replenish mahseer population in these rivers. The mahseer seed stocking programme can significantly improve the status of mahseer fishery in lentic and lotic aquatic ecosystem of Garhwal Himalaya. It could be therefore, concluded that conservation and management of aquatic natural habitat should be protected for enhancement of viable population size of mahseer species and restore the genetic loss under mahseer conservation programme in aquatic ecosystem of Himalayan region.

\section{ACKNOWLEDGEMENTS}

The author is highly thankful to Joint Director, Uttarakhand State Fisheries Department, Dehradun (U.K.) for providing all the necessary facilities of fishing and collection of mahseer specimen and hatchery to carry out the research work.

\section{REFERENCES}

Bhatt. J. P., Nautiyal, P. and Singh H.R. (2000). Population structure of Himalayan Mahseer, a large cyprinid fish in the regulated foothill section of the river Ganga. Fisheries Research, 44: 267 - 271.

CAMP (1998). Conservation assessment management plan. Workshop report. pp.156.

Chaturvedi, S. K. (1976). Spawning biology of mahseer, Tor tor (Ham.), J. Bombay Nat. Hist. Soc., 73 (1): 63- 73.

Das, P. (1994). Strategies for conserving threatened fisheries. In: Dehadrai, P. V., P. Das and S.R. Verma (eds). Threatened fishes of India. Pub. No. 4: 307 - 310.

Day, F. (1878). The Fishes of India, William Dawsan and Sons London., pp. 591.

Day, F. (2007). The Fishes of India: a natural history of the fishes inhabit the sea and freshwaters of India, Burma and Ceylon, published by Jagmander Book Agency, New Delhi, pp. 205.

Jayaram, K. C. (1999). The freshwater fishes of the Indian region. Narendra Publishing House, Delhi, pp.551.

Jhingran A. G. (1990). Restoration of fisheries in the Ganga river system. Working paper of the technical sub committee of the co-ordination committee on restoration of fisheries in Ganga river system. pp. 19.

Kar, D. (2003). Tor sp. (mahseer) in river Mat in Mizoram. Aquacult 3(2): 229 - 234.

Khan, H. (1939). Study of the sex organ of mahseer. J. Bombay Nat. Hist. Soc., 41(1): $231-243$.

Khanna, D. R., Malik, D. S. and Rupendra (1998). Fish fauna of the river Ganga at Rishikesh (U.P.). J. Natcon., 10(2): 211-213.

Malik, D. S., Sehgal K.L. and Khanna D.R. (1998). Ichthyodiversity and conservation of endangered fish species in upland waters. Him. J. Env. Zool., 12: 199 - 204.

Mittermeier, R. A. and Mittemeier C.G. (1997). Megadiversity: Earth's Biologically Wealthiest Nation. In: McAllister, D.E., A. L., Hamilton and B. Harvery (Eds.). Global freshwater Biodiversity, Sea Wind, Cemex, Mexico City, 11: 1- 140 .

Moza, U., Mishra, D.N. and Hajra. A. (2005). Fishery resources of river Yamuna in Himalayas, published proceeding Aquatic resource management in Hills, (Eds), K.K. Vass, et al., NRC CWF Bhimtal (U.K.) pp. 246.

National commission of Agriculture (1976). Threatened fishes of India : A report published by Ministry of Agriculture, New Delhi, pp: 96.

Nath, M. M., Jasbir R.K., and Chopra, M.M. (1994). A report on the decline of sport fish in the rivers and streams of the hill of Uttar Pradesh with particular reference to the Doon valley region. "Threatened Fishes of India" NATCON publication. 4: $219-227$.

Ogale, S. N. (2000). Mahseer hatchery-Planning and management. Fishing Chimes, 19 (10-11):69-77.

Pathani, S. S. (1978). A note on ecology and conservation of mahseer, Tor tor and Tor putitora (Ham.) in Kumaon lakes. Env. India, 1: 36-37.

Sehgal, K. L. (1974). Report on the work done by the cold water fisheries. Research Unit of CIFRI in Kashmir during 1966 - 71, Mimeographed: 1-3.

Sehgal, K. L. (1991). Artificial propagation of Golden mahseer, Tor putitora (Ham.) in the Himalaya. NRCCWF Sp. Publ., 2: 12.

Sehgal, K. L. (1992). Cold water fishes and fishery of the Himalaya, Part-I. River and streams, F.A.O. Publication. pp. 150 .

Sehgal, K. L. and Kumar, Kuldeep (1977). Final project report on induced breeding and rearing of mahseer (Tor putitora) seed in running water ponds. CIFRI Mimeo: pp.12.

Sehgal, K. L. and Malik, D. S. (1991). Efficiency of flowthrough system for seed production of Tor putitora (Ham.) at Bhimtal, Kumaon Himalaya. Indian J. Fish., 39 (2): 134 $-137$.

Sehgal, K. L. and Malik, D. S. (1996). Induced breeding practice of Tor putitora (Ham.) and its conservation in Kumoun lakes. Him. J. Env. Zool., 10: 27 - 29.

Singh, H.R., Dobriyal, A.K. and Nautiyal, P.(1987). Spawning patterns and environmental regulation of spawning in hillstream fishes. In: The Endocrine system and the Environment. Ed. Follett. B. K. et al., Japan Sci. Soc. Press. Tokyo. Springer-Verlag, Berlin, pp.1-11.

Soni, V. (1998). Angling Scene in India with reference to Kashmir and U.P. "Fish Genetics and Bio-diversity Conservation" NATCON Publication, 5: 55- 62.

Talwar, P.K. and Jhingran, A.G. (1991). Inland fishes of India and adjacent countries. Oxford and IBH Publishing Co. Pvt. Ltd. New Delhi, 2 Volumes: xix + pp.1158.

Welcomme R.L. (1985). River fisheries. FAO Fish Tech. paper : 262 - 318 . 